Annals of Plant Sciences

ISSN: 2287-688X

OPEN ACCESS

www.annalsofplantsciences.com

Research Article

\title{
Preliminary phytochemical screening of Lantana camara L., a major invasive species of Kerala, using different solvents
}

Sushama Raj R.V.

Department of Botany, H.H.M.S.P.B. N.S.S. College for Women, Neeramankara, Thiruvananthapuram, Kerala, India.

Received: 10/22/2017; Accepted: 10/29/2017

\begin{abstract}
Plants and plant extracts have important role in modern medicine as their chemical and medicinal constituents are found in natural form. The secondary metabolites represent a large reservoir of structural moieties which work together exhibiting a wide range of biological activities. Plants and plant based products are bases of many modern pharmaceuticals that are currently in use for various diseases. Lantana camara L., also known as big - sage or wild - sage is one of the major invasive weed in India. Six different solvents viz; distilled water, acetone, alcohol, chloroform, petroleum ether and benzene were used to obtain extracts from powdered leaves and roots of Lantana camara, L. The extracts were subjected to qualitative phytochemical screening using standard procedures. Of the 15 phytochemicals tested, 10 were found in various solvent extracts of Lantana camara, L. By this study, it was confirmed that the selected plant species is a potent source of useful drugs. Present day, particularly in India, Lantana camara, L. is considered as a threat to our biodiversity. So a controlled management is necessary to make use its medicinal use.
\end{abstract}

Keywords: Lantana camara, phytochemical screening, leaves, root

\section{Introduction}

Plant kingdom is a treasure house of potential drugs and in the recent years there has been an increasing awareness about the importance of medicinal plants. Drugs from the plants are easily available, less expensive, safe, and efficient with little or no side effects. The plants which have been selected for medicinal use over thousands of years constitute the most obvious choice of examining the current search for therapeutically effective new drugs such as anticancer drugs (Dewick, 1996), antimicrobial drugs (Phillipson, 1996), antihepatotoxic compounds (Ncube et al., 2008). According to World Health Organization (WHO), medicinal plants would be the best source to obtain variety of drugs. About $80 \%$ of individuals from developed countries use traditional medicines, which has compounds derived from medicinal plants. However, such plants should be investigated to better understand their properties, safety, and efficiency (Mann, 1978).

Phytochemicals are bioactive chemicals of plant origin. They are regarded as secondary metabolites because the plants that manufacture them may have little need for them. They are naturally synthesized in all parts of the plant body, such as bark, leaves, stem, root, flower, fruits, seeds etc. i.e. any part of the plant body may contain these active compounds (Cowan, 1999). The quantity and quality of phytochemicals present in plant parts may contain active compounds. The quantity and quality of phytochemicals present in plant parts may differ from one part to another. In fact, there is lack of information on the distribution of the biological activity in different plant parts essentially related to the difference in distribution of active compound which are frequent in some plant parts (Mojab, 2003; Parekh and Chanda, 2008; Parekh and Chanda, 2009).

Medicinal plants contain some organic compounds which provide definite physiological action on the human body and these bioactive substances include tannins, alkaloids, carbohydrates, terpenoids, steroids and flavonoids (Edoga, 2005; Mann, 1978). These compounds are synthesized by primary or rather secondary metabolism of living organisms. Secondary metabolites are chemically and taxonomically extremely diverse compounds with obscure function. They are widely used in the human therapy, veterinary, agriculture, scientific research and countless other areas (Vasu, 2009). A large number of phytochemicals belonging to several chemical classes have been shown to have inhibitory effects on all types of microorganisms in vitro (Cowan, 1999).

Lantana camara, often planted as a garden variety, has spread from its native Central and South America to more than 50 different countries, where it has become an invasive species. It spread from the Americas into the rest of the world when it was brought back to Europe by Dutch explorers and cultivated widely, soon spreading into Asia and Oceania, where it established itself as a notorious weed. It is a small perennial shrub

\footnotetext{
*Corresponding Author:

Dr. Sushama Raj R.V.,

Asst. Prof. \& Head, Department of Botany,

H.H.M.S.P.B. N.S.S. College for Women,

Thiruvananthapuram, Kerala, India.

E-mail:drsushamarajrv@gmail.com
}

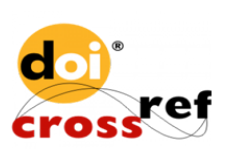


which can grow to around $2 \mathrm{~m}$ tall and form dense thickets in a variety of environments. The plant is considered to be a weed in large areas of the tropics, where it has established itself. In agricultural areas or secondary forests, it can become the dominant understorey shrub, crowding out other native species and reducing biodiversity. The formation of dense thickets of $L$. camara can significantly slow down the regeneration of forests by preventing the growth of new trees. Although L. camara is itself quite resistant to fire, it can change fire patterns in a forest ecosystem by altering the fuel load to cause a build-up of forest fuel which increases the risk of fires spreading to the canopy. This can be particularly destructive in dry, arid areas where fire can spread quickly and lead to the loss of large areas of natural ecosystem.

Lantana camara reduces the productivity in pasture through the formation of dense thickets which reduce growth of crops as well as make harvesting more difficult. There are also secondary impacts, including the finding that mosquitos which transmit malaria and tsetse flies in Africa shelter within the bushes of L. camara. The present study is designed to explore the preliminary phytochemical analysis of Lantana camara in a vision of to explore its phytochemical spectrum in favour of nature and mankind.

\section{Materiala and Methods}

\section{Collection of plant material}

The leaves and root of Lantana camara, L. were collected from three different locations of Thiruvananthapuram. Collected leaves are shade dried for one to two weeks. Constant monitoring was carried out to avoid microbial contamination. The dried plant materials was taken and ground using motor and pestle to obtain a fine powder. The powder was further passed through a $2 \mathrm{~mm}$ sieve to obtain finer particles. The powdered samples were stored in a clean glassware container and stored in low temperature until needed for analysis (Das et al., 2010).

\section{Preparation of plant extracts}

5 gram of dried and powdered sample was taken. It was put separately in acetone, petroleum ether, chloroform, ethyl alcohol, benzene and water. Mixed well and extracted for 24 hours on a stirrer with continuous stirring. After extraction, the extracts were filtered through Whatman No.1 filter paper, centrifuged the filtrate for clarification, stored for further phytochemical investigations (Das et al., 2010).

\section{Preliminary phytochemical investigations}

Analysis on the presence of both primary metabolites and secondary metabolites such as proteins, amino acids, carbohydrates, alkaloids, saponins, phytosterols, glycosides, phenols, tannins, flavonoids, steroids, terpenoids, and vitamin $C$ were assessed according to the standard procedure, as described below, were used (Harborne, 1998).

\section{Test for Proteins}

Biuret Test:- Test solution was treated with equal volume of $10 \%$ sodium hydroxide solution and two drops of $1 \%$ copper sulphate solution, mixed well and observed for the formation of violet/pink colour. If it is so, presence of proteins was detected.

Xanthoproteic Test:- Two $\mathrm{ml}$ of extracts were treated with few drops of conc. Nitric acid. Mixed well. Formation of light to dark yellow colour was noted which indicates the presence of proteins.

Millon's Test:- Two $\mathrm{ml}$ of crude extract when mixed with $2 \mathrm{ml}$ of Millon's reagent, if a white precipitate appeared which turned red upon gentle heating and disappeared on cooling confirmed the presence of protein.

\section{Test for Free Amino Acids}

Ninhydrin Test:- Test solution when boiled with $0.2 \%$ solution of Ninhydrin. Formation of purple color suggests the presence of free amino acids.

\section{Test for Carbohydrates}

Benedict's test:- Test solution was mixed with few drops of Benedict's reagent (alkaline solution containing cupric citrate complex) and boiled in water bath, observed for the formation of reddish brown precipitate to show a positive result for the presence of carbohydrate.

Molisch's Test:- Filtrates were treated with 2 drops of alcoholic $\alpha$-naphthol solution in a test tube. Formation of the violet ring at the junction indicates the presence of Carbohydrates.

Fehling's Test:- Filtrates were hydrolysed with dil. $\mathrm{HCl}$, neutralized with alkali and heated with Fehling's A \& B solutions. Formation of red precipitate indicates the presence of reducing sugars.

\section{Test for Alkaloids}

Wagner's Test:- A fraction of extract was treated with 3-5drops of Wagner's reagent $[1.27 \mathrm{~g}$ of iodine and $2 \mathrm{~g}$ of potassium iodide in $100 \mathrm{ml}$ of water] and observed for the formation of reddish brown precipitate (or colouration) which indicates the presence of alkaloids.

Mayer's Test:-Filtrates were treated with Mayer's reagent (Potassium Mercuric Iodide). Formation of a yellow coloured precipitate indicates the presence of alkaloids.

\section{Test for Saponins}

Foam Test:- Test solution was mixed with water and shaken and observed for the formation of 
froth, which should be stable for 15 minutes. This result indicates the presence of Saponins.

Froth Test:- Extracts were diluted with distilled water to $20 \mathrm{ml}$ and this was shaken in a graduated cylinder for 15 minutes. Formation of $1 \mathrm{~cm}$ layer of foam indicates the presence of saponins.

\section{Test for Phytosterols}

Salkowski's Test:- Extracts were treated with chloroform and filtered. The filtrates were treated with few drops of Conc. Sulphuric acid, shaken and allowed to stand. Appearance of golden yellow colour indicates the presence of triterpenes.

\section{Test for Glycosides}

Liebermann's test:- Crude extract was mixed with each of $2 \mathrm{ml}$ of chloroform and $2 \mathrm{ml}$ of acetic acid. The mixture was cooled in ice. Carefully concentrated $\mathrm{H}_{2} \mathrm{SO}_{4}$ was added. A colour change from violet to blue to green indicated the presence of steroidal nucleus, i.e., glycine portion of glycoside.

Salkowski's test:- Crude extract was mixed with $2 \mathrm{ml}$ of chloroform. Then $2 \mathrm{ml}$ of concentrated $\mathrm{H}_{2} \mathrm{SO}_{4}$ was added carefully and shaken gently. A reddish brown colour indicated the presence of steroidal ring, i.e., glycone portion of the glycoside.

Keller Killiani Test:- Test solution was treated with few drops of glacial acetic acid and Ferric chloride solution and mixed. Concentrated sulphuric acid was added, and observed for the formation of two layers. Lower reddish-brown layer and upper acetic acid layer which turns bluish green would indicate a positive test for glycosides.

\section{Test for Phenols}

Ferric Chloride Test:- Extracts were treated with 3-4 drops of ferric chloride solution. Formation of bluish black colour indicates the presence of phenols.

\section{Test for Tannins}

Gelatin Test:- To the extract, 1\% gelatin solution containing sodium chloride was added. Formation of white precipitate indicates the presence of tannins.

Braymer's test:- $2 \mathrm{ml}$ of extract was treated with $10 \%$ alcoholic ferric chloride solution. Formation of blue or greenish colour solution shows the presence of Tannins.

\section{Test for Flavonoids}

Shinoda test:- Crude extract was mixed with few fragments of magnesium ribbon. Con. $\mathrm{HCl}$ was added drop wise. Pink scarlet colour appeared after few minutes which indicated the presence of flavonoids.

Alkaline reagent test:- Crude extract was mixed with $2 \mathrm{ml}$ of $2 \%$ solution of $\mathrm{NaOH}$. An intense yellow colour was formed which turned colourless on addition of few drops of diluted acid which indicated the presence of flavonoids.

\section{Test for Steroids}

Liebermann Burchard test:- Crude extract was mixed with few drops of acetic anhydride, boiled and cooled. Concentrated sulphuric acid was then added from the sides of the test tube and observed for the formation of a brown ring at the junction of two layers. Green coloration of the upper layer indicate a positive test for steroids.

\section{Test for Vitamin C}

DNPH Test:- Crude extract was treated with Dinitrophenyl hydrazine dissolved in Con. $\mathrm{H}_{2} \mathrm{SO}_{4}$. The formation of yellow precipitate would suggest the presence of Vitamin C.

\section{Test for Phlobatannins}

Precipitate test:- Deposition of a red precipitate when $2 \mathrm{mls}$ of extract was boiled with $1 \mathrm{ml}$ of $1 \%$ aqueous hydrochloric acid was taken as evidence for the presence of phlobatannins.

\section{Test for Quinones}

HCl Test:- A small amount of extract was treated with concentrated HCL and observed for the formation of yellow precipitate (or coloration).

\section{Test for Oxalate}

Acid Test:- To $3 \mathrm{ml}$ portion of extracts were added a few drops of ethanoic acid glacial. A greenish black coloration indicates presence of oxalates.

\section{Results and Discussion}

Results obtained for qualitative screening of phytochemicals in different parts of Lantana camara, L. is presented in Table 1. Of the fifteen phytochemicals screened for, ten were found to be present in various solvent extracts. They are proteins, free amino acids, carbohydrates, alkaloids, saponins, phenols, tannins, flavonoids, steroids and vitamin C. In all, more phytochemicals were found present in extract prepared with distilled water. Remarkably, phytosterols, glycosides, quinones, phlobatannins and oxalates were not present in all extracts from different parts. Among the extracts tested maximum result was observed in distilled water extract and least result showed in Acetone extract. According to Tiwari et al., the factors affecting the choice of solvent are; quantity of phytochemicals to be extracted, rate of extraction, diversity of different compounds extracted, diversity of inhibitory compounds extracted, ease of subsequent handling of the extracts, toxicity of the solvent in the bioassay process, potential health hazard of the extractant. The logic in using different solvents when screening for phytochemicals in plant materials was clearly validated in present study. For instance, the results shows that alkaloids were exceptionally present in petroleum ether 
extract but absent in all other extracts. Steroids showed their presence in alcohol and chloroform extracts. This corroborates the reports of Misra et al.
Proteins and carbohydrates showed their presence in all extracts irrespective to the solvents and plant parts.

Table 1. Result of phytochemical screening of Lantana camara, L. + indicates presence and - indicates absence.

\begin{tabular}{|c|c|c|c|c|c|c|c|c|c|c|c|c|}
\hline \multirow{3}{*}{ Phytochemicals } & \multicolumn{12}{|c|}{ Extract } \\
\hline & \multicolumn{2}{|c|}{ Distilled Water } & \multicolumn{2}{|c|}{ Acetone } & \multicolumn{2}{|c|}{ Alcohol } & \multicolumn{2}{|c|}{ Chloroform } & \multicolumn{2}{|c|}{ P.Ether } & \multicolumn{2}{|c|}{ Benzene } \\
\hline & Leaves & Root & Leaves & Root & Leaves & Root & Leaves & Root & Leaves & Root & Leaves & Root \\
\hline \multicolumn{13}{|l|}{ Proteins } \\
\hline Biuret Test & + & + & - & - & + & + & + & + & + & + & + & + \\
\hline Xanthoproteic Test & + & + & - & - & + & + & + & + & + & + & + & + \\
\hline $\begin{array}{l}\text { Millon's Test } \\
\text { Amino Acids }\end{array}$ & + & + & - & - & + & + & + & + & + & + & + & + \\
\hline $\begin{array}{l}\text { Ninhydrin Test } \\
\text { Carbohydrates }\end{array}$ & + & + & - & - & + & + & + & + & + & + & + & + \\
\hline Benedict's test & + & + & - & - & + & + & + & + & + & + & + & + \\
\hline Molisch's Test & + & + & - & - & + & + & + & + & + & + & + & + \\
\hline $\begin{array}{l}\text { Fehling's Test } \\
\text { Alkaloids }\end{array}$ & + & + & - & - & + & + & + & + & + & + & + & + \\
\hline Wagner's Test & - & - & - & - & - & - & - & - & + & + & - & - \\
\hline $\begin{array}{l}\text { Mayer's Test } \\
\text { Saponins }\end{array}$ & - & - & - & - & - & - & - & - & + & + & - & - \\
\hline Foam Test & + & + & - & - & - & - & - & - & - & - & + & + \\
\hline $\begin{array}{l}\text { Froth Test } \\
\text { Phytosterols }\end{array}$ & + & + & - & - & - & - & - & - & - & - & + & + \\
\hline $\begin{array}{l}\text { Salkowski's Test } \\
\text { Glycosides }\end{array}$ & - & - & - & - & - & - & - & - & - & - & - & - \\
\hline Liebermann's test & - & - & - & - & - & - & - & - & - & - & - & - \\
\hline Salkowski’s test & - & - & - & - & - & - & - & - & - & - & - & - \\
\hline $\begin{array}{l}\text { Keller Killiani Test } \\
\text { Phenols }\end{array}$ & - & - & - & - & - & - & - & - & - & - & - & - \\
\hline $\begin{array}{l}\text { Ferric Chloride Test } \\
\text { Tannins }\end{array}$ & + & + & + & + & + & + & - & - & + & + & + & + \\
\hline Gelatin Test & + & + & + & + & + & + & - & - & - & - & - & - \\
\hline $\begin{array}{l}\text { Braymer's test } \\
\text { Flavonoids }\end{array}$ & + & + & + & + & + & + & - & - & - & - & - & - \\
\hline Shinoda test & + & + & - & - & + & + & + & + & - & - & - & - \\
\hline $\begin{array}{l}\text { Alkaline reagent test } \\
\text { Steroids }\end{array}$ & + & + & - & - & + & + & + & + & - & - & - & - \\
\hline $\begin{array}{l}\text { Liebermann Burchard test } \\
\text { Vitamin C }\end{array}$ & - & - & - & - & + & + & + & + & - & - & - & - \\
\hline $\begin{array}{l}\text { DNPH Test } \\
\text { Phlobatannins }\end{array}$ & + & + & - & - & - & - & - & - & - & - & - & - \\
\hline $\begin{array}{l}\text { Precipitate test } \\
\text { Quinones }\end{array}$ & - & - & - & - & - & - & - & - & - & - & - & - \\
\hline $\begin{array}{l}\mathrm{HCl} \text { Test } \\
\text { Oxalate }\end{array}$ & - & - & - & - & - & - & - & - & - & - & - & - \\
\hline Acid Test & - & - & - & - & - & - & - & - & - & - & - & - \\
\hline
\end{tabular}

Phytochemical screening of the extracts of Lantana camara, L. revealed the presence of alkaloids, steroids, flavonoids, amino acids, tannins, and phenols (table1). These compounds have significant application against human pathogens, including those that cause enteric infections (El-Mahmood et al.). The result indicates that Lantana camara, L. hold promises as source of pharmaceutically important phytochemicals. Alkaloids play some metabolic role and control development in living system. They are also involved in protective function in animals and are used as medicine especially the steroidal alkaloids. Tannins are known to inhibit pathogenic fungi, is present in hexane extract. The flavonoids and phenolic compounds in plant have been reported to exert multiple biological effects including antioxidant, free radical scavenging abilities, anti-inflammatory, anti-carcinogenic etc.

\section{Conclusion}

In present world, it is necessary to introduce new and biologically safe and active drugs for an eco-friendly life style. Phytochemicals found present in the Lantana camara, L. indicates their potential as a source of principles that may supply novel medicines. In Present day, Lantana camara, L. is considered as a major invasive species. It is possible, that we can use this plant as a potent source of valuable drugs. Detailed study is needed to reveal its complete phytochemical profile which includes both qualitative and quantitative analysis which will be useful to mankind in future. So a detailed study is therefore suggested to ascertain their antimicrobial, antiplasmodic and antihelminthic activities. Furthermore, isolation, purification and characterization of the phytochemicals found in this species may introduce us to a future medicine that will change the life of mankind. 


\section{References}

1. Bibitha B, Jisha VK, Salitha CV, Mohan S, Valsa AK., Antibacterial activity of different plant extracts. Short Communication. Indian J Microbiol, 42 (2002): $361-363$.

2. Cowan M. M, Plant products as antimicrobial agents. Clinical microbiology reviews, 12.4 (1999): 564 - 582.

3. Das K, Tiwari RKS, Shrivastava DK, Techniques for evaluation of medicinal plant products as antimicrobial agent: Current methods and future trends, Journal of Medicinal Plants Research, 4.2 (2010): $104-111$.

4. Dewick, PM, Tumor inhibition from plants, Tease and Evans, (1996): 210-214.

5. Edoga HO, Okwu DE, Mbaebie BO, Phytochemicals constituents of some Nigerian medicinal plants, Afr. J. Biotechnol, 4.7 (2005): 685688.

6. El-Mahmood, AM, Doughari, JH, and Chanji, FJ, Invitro antibacterial activities of crude extracts of Nauclea latifolia and Daniella oliveri, Sci. Res. Essay, 3.3 (2008): $102-105$.

7. Harbone SV, Biochemistry of plant Phenolies, Recent Advances in Phytochemistry, 12 (1973): 760.

8. Harbone JB, Role of secondary metabolites in chemical defence mechanisms in plants. Bioactive compounds from plants. Ciba foundation symposium, Wiley Chichester, 154 (1990): 126-139.

9. Harborne, JB, Phytochemical Methods, A guide to modern techniques of plant analysis. Chapman and Hall, New York. 3rd Edn, (1998): 1-150.
10. Mann, J, Secondary Metabolism. Oxford University press, London. (1978): 154-57.

11. Mojab, F, Kamalinejad, M, Ghaderi, N, Vanidipour, HR, Phytochemicals screening of some species of Iranian plants. Iran, J. Pharm. Res, 3 (2003): 77-82.

12. Ncube NS, Afolayan AJ, Okoh AI, Assessment techniques of antimicrobial properties of natural compounds of plant origin: current methods and future trends, African Journal of Biotechnology, 7.12 (2008): 1797-1806.

13. Parekh, J, Chanda, S, Phytochemicals screening of some plants from western region of India, Plant Arch, 8 (2008): 657- 662.

14. Parekh, J, Chanda, S, Antibacterial and phytochemical studies on twelve species of Indian medicinal plants, Afr. J. Biomed. Res, 10 (2007): 175181.

15. Phillipson, JD, Wright CW, Plants With Antiprotozoal Activity: Tease and Evans, Pharmacognosy, WB Saunders Company, London, 14th Edn, (1996): 612.

16. Vasu K, Goud JV, Suryam A, Singara, Chary MA, Biomolecular and phytochemical analyses of three aquatic angiosperms, Afr. J. microbiol. Res, 3.8 (2009): 418-421.

\section{Cite this article as:}

Sushama Raj R.V. Preliminary phytochemical screening of Lantana camara L., a major invasive species of Kerala, using different solvents. Annals of Plant Sciences 6.11 (2017) pp. 1794-1798

doi: http://dx.doi.org/10.21746/aps.2017.6.11.13 